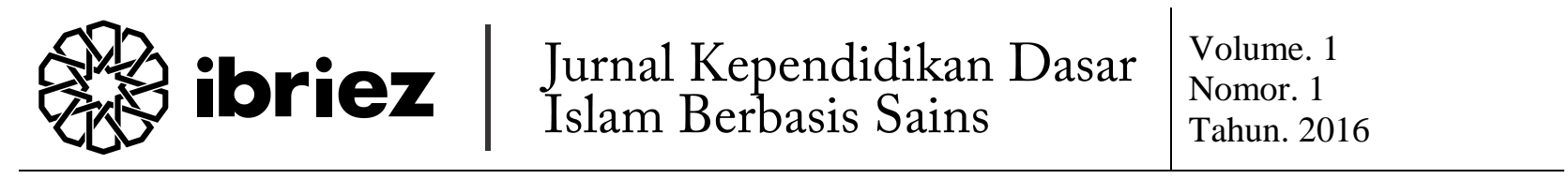

\section{Implementasi Penanaman Karakter Melalui Matematika Pada Kurikulum 2013}

\author{
Edi Irawan \\ Jurusan Tarbiyah IAIN Ponorogo \\ nawariide@stainponorogo.ac.id
}

\begin{abstract}
Abstrak
Budaya dan karakter diyakini menjadi kunci sekaligus solusi pelbagai permasalahan sosial di masyarakat. Karenanya, penanaman nilai budaya dan karakter menjadi prioritas nasional, tidak terkecuali melalui dunia pendidikan. Seiring dengan hal tersebut, frame pendidikan nasional juga mengalami pergeseran dan perbaikan seiring dengan hadirnya kurikulum 2013. Penelitian ini bertujuan untuk mendeskripsikan implementasi penanaman nilai budaya dan karakter bangsa pada kurikulum 2013, utamanya melalui mata pelajaran matematika. Pendekatan yang digunakan adalah deskriptif kualitatif dengan metode multi kasus. Subjek pada penelitian ini adalah kepala sekolah, guru dan siswa pada tiga sekolah di Kabupaten Pacitan, yakni SDN Ploso I, SMPN 1 Pacitan, maupun di SMAN 1 Pacitan. Data diperoleh dari penelusuran dokumen, observasi, angket, wawancara mendalam, dan focus group discussion (FGD). Hasil penelitian menunjukkan bahwa penanaman nilai budaya dan karakter juga menjadi ruh dalam kurikulum 2013. Secara eksplisit, berbagai muatan nilai budaya dan karakter bangsa tercantum standar kompetensi lulusan, rumusan kompetensi aspek sikap spiritual, dan rumusan kompetensi aspek sikap sosial. Demikian halnya dengan pembelajaran matematika, sangat relevan untuk menanamkan nilai budaya dan karakter bangsa, melalui pembelajaran tidak langsung. Problematikanya bertalian erat dengan problematika kurikulum 2013, yakni keluasan materi, sistematika materi, penilaian, dan proses adaptasi guru.
\end{abstract}

Kata Kunci: karakter, kurikulum 2013, matematika

\section{A. PENDAHULUAN}

Di era mondial dewasa ini, pudarnya nilai budaya dan karakter bangsa ditengarai menjadi pemantik menjamurnya pelbagai permasalahan sosial di masyarakat. Banyak seminar, simposium, lokakarya, berita media cetak, dan media elektronik, serta sosial media yang mengangkat topik ini. Para ahli, para pengamat pendidikan, para tokoh masyarakat, dan para pengamat sosial kerap mengangkat realita mulai lunturnya nilai budaya dan karakter bangsa melalui berbagai forum dan media. Pelbagai indikator yang dijadikan sebagai bukti empiris di masyarakat adalah maraknya kasus-kasus korupsi, kekerasan, kejahatan seksual, perusakan, perkelahian massa, tawuran, kehidupan ekonomi yang konsumtif, kehidupan politik yang tidak produktif 1 .

\footnotetext{
${ }^{1}$ Tim Penyusun, Pengembangan Pendidikan Budaya Dan Karakter Bangsa (Jakarta: Pusat Kurikulum Badan Pusat Penelitian dan Pengembangan Kemendiknas, 2010).
} 
Pelbagai alternatif solusi telah ditawarkan untuk kembali kepada khitah budaya dan karakter bangsa. Pemerintah sudah berupaya untuk mengarusutamakan pembangunan karakter bangsa. Hal ini secara eksplisit tertuang dalam Rencana Pembangunan Jangka Panjang Nasional Tahun 2005-2025, yang menempatkan pendidikan karakter sebagai misi pertama dari delapan misi guna mewujudkan visi pembangunan nasional ${ }^{2}$.

Implementasinya, secara makro pendidikan karakter dilaksanakan secara menyeluruh dan berkesinambungan dengan intervensi dari pelbagai pihak, baik satuan pendidikan, keluarga, maupun masyarakat sebagaimana tercantum pada gambar $1 .{ }^{3}$
Pembentukan karakter menjadi perhatian utama dalam pendidikan nasional. Secara eksplisit pendidikan nasional memiliki fungsi untuk mengembangkan kemampuan dan membentuk watak serta peradaban bangsa yang bermartabat dalam rangka mencerdaskan kehidupan bangsa, bertujuan untuk berkembangnya potensi peserta didik agar menjadi manusia yang beriman dan bertakwa kepada Tuhan Yang Maha Esa, berakhlak mulia, sehat, berilmu, cakap, kreatif, mandiri, dan menjadi warga negara yang demokratis serta bertanggung jawab ${ }^{4}$.

Aktualisasi pendidikan karakter dalam konteks mikro berpusat pada satuan pendidikan secara holistik. Satuan

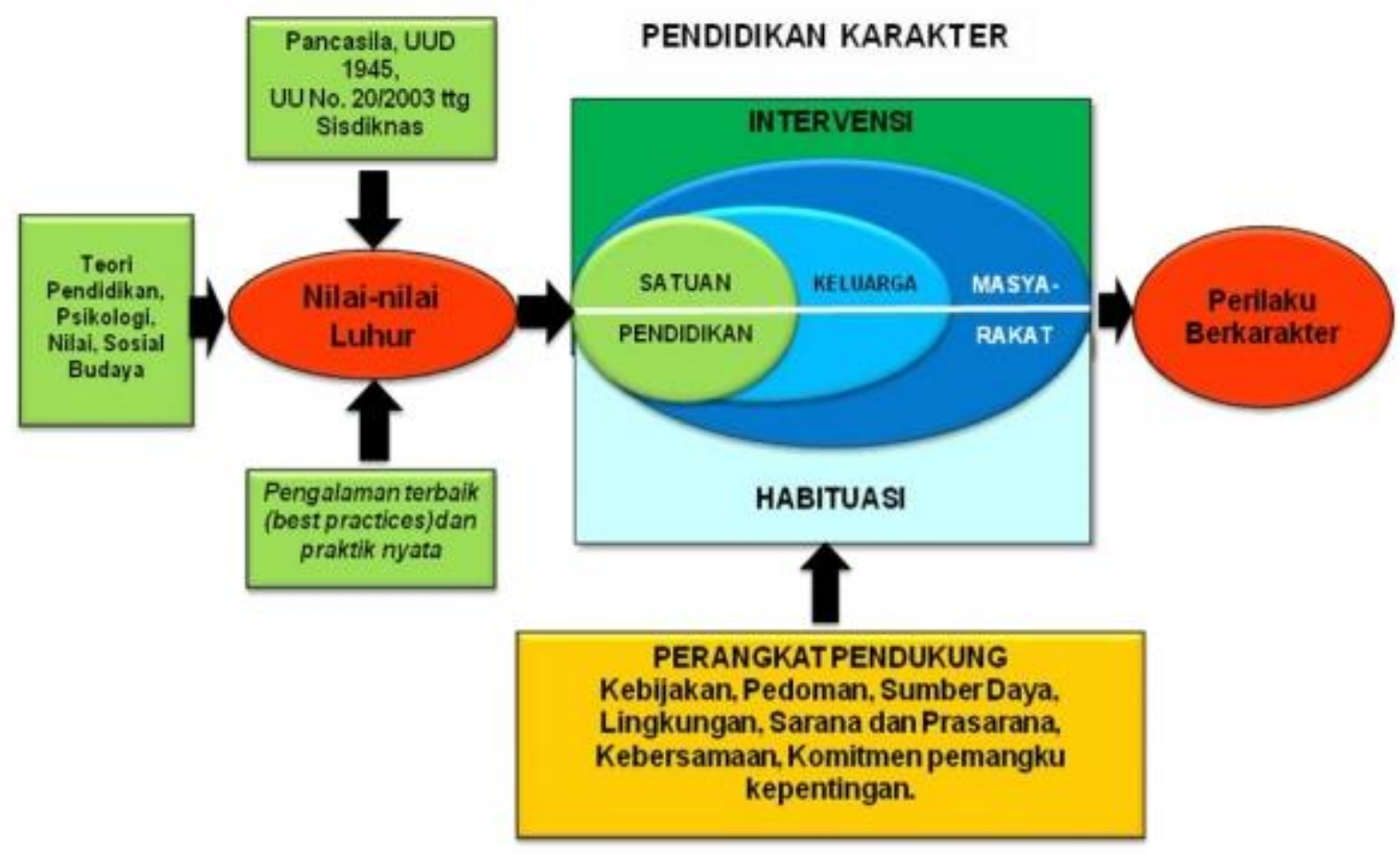

Gambar 1. Konteks Makro Pendidikan Karakter

\footnotetext{
2 “Undang-Undang RI Nomor 17 Tahun 2007 Tentang Rencana Pembangunan Jangka Panjang Nasional Tahun 2005-2025," 2007.

${ }^{3}$ Pemerintah Republik Indonesia, Kebijakan Nasional Pembangunan Karakter Bangsa Tahun 2010-2025 (Jakarta: Pemerintah Republik Indonesia, 2010).
}

pendidikan merupakan sektor utama yang secara optimal dituntut untuk mampu memanfaatkan dan memberdayakan semua

\footnotetext{
4 "Undang-Undang Republik Indonesia Nomor 20 Tahun 2003 Tentang Sistem Pendidikan Nasional," 2003.
} 
lingkungan belajar yang ada untuk matematika, hakikat proses belajar menginisiasi, memperbaiki, menguatkan, dan menyempurnakan secara terusmenerus proses pendidikan karakter di satuan pendidikan.

Secara teknis, pengembangan karakter dilaksanakan melalui empat kegiatan, yakni melalui kegiatan belajarmengajar di kelas, melalui kegiatan keseharian dalam bentuk pengembangan budaya satuan pendidikan, melalui kegiatan ko-kurikuler dan/atau ekstra kurikuler, serta melalui kegiatan keseharian di rumah dan masyarakat (gambar 2). ${ }^{5}$

Pengembangan karakter dalam mengajar matematika, hakikat pembudayaan matematika sekolah ${ }^{6}$. Di sisi lain, secara umum, pengembangan karakter harus mampu menjelaskan hakikat karakter, implementasi dan contohcontohnya, menjelaskan sumber-sumber pengetahuan dan nilai-nilai dan macammacam karakter yang harus digali dan dikembangkan, ukuran atau pembenaran kelaziman karakter dalam lingkup pribadi, kelompok, berbangsa dan secara universal. Jika karakter dipandang sebagai nilai yang perlu digali, dikembangkan dan diimplementasikan, maka konteks ruang

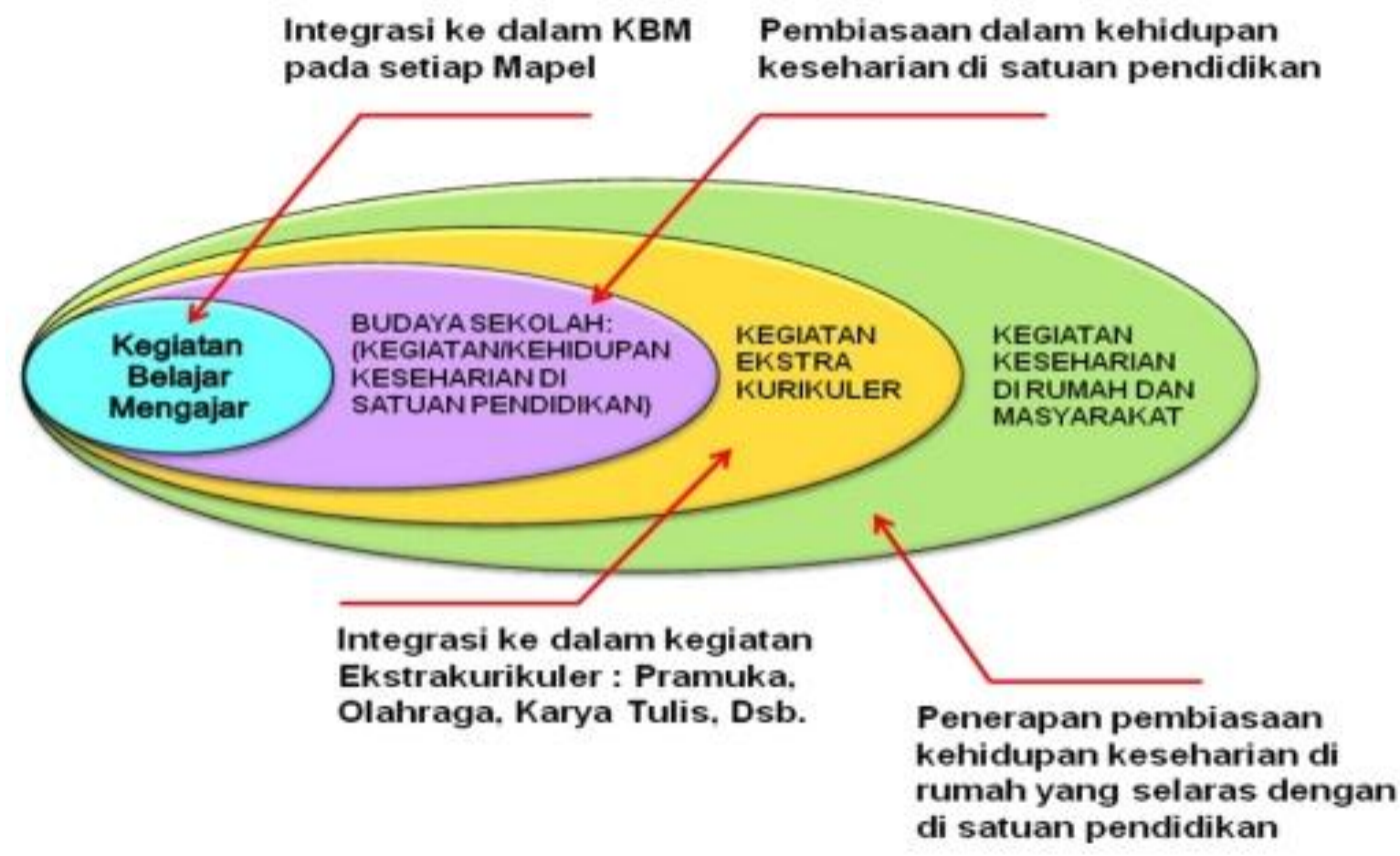

Gambar 2. Konteks Mikro Pendidikan Karakter

pendidikan matematika di sekolah mempunyai aspek pemahaman tentang hakikat matematika, hakikat matematika sekolah, hakikat pendidikan matematika, hakikat nilai matematika, hakikat belajar

${ }^{5}$ Pemerintah Republik Indonesia, Kebijakan Nasional Pembangunan Karakter Bangsa Tahun 2010-2025.

\footnotetext{
${ }^{6}$ Marsigit, "Pengembangan Nilai-Nilai Matematika Dan Pendidikan Matematika Sebagai Pilar Pembangunan Karakter Bangsa," in Seminar Nasional Pengembangan Nilai-Nilai Dan Aplikasi Dalam Dunia Matematika Sebagai Pilar Pembangunan Karakter Bangsa (Seminar Nasional, Semarang: Universitas Negeri Semarang, 2011).
} 
dan waktu serta arah pengembangannya menjadi sangat penting?.

Pendidikan matematika dapat dipandang sebagai suatu keadaan atau sifat atau bahkan nilai yang bersinergis dengan pengembangan karakter. Perpaduan atau sinergi antara pengembangan karakter dan pendidikan matematika merupakan keadaan unik sebagai suatu proses pembelajaran yang dinamis yang merentang dalam ruang dan waktunya pembelajaran matematika yang berkarakter konteks ekonomi, sosial, politik, dan budaya bangsa. Dengan demikian, pengembangan karakter dalam pendidikan matematika merupakan potensi sekaligus fakta yang harus menjadi bagian tidak terpisahkan bagi setiap insan pengembang pendidikan, baik pendidik, tenaga pendidik maupun pengambil kebijakan pendidikan.

Pembentukan karakter siswa menjadi hidden goal yang harus dicapai dari serangkaian pendidikan di Indonesia. Baik pendidikan formal maupun non formal. Penanaman pendidikan karakter di sekolah sangat dibutuhkan karena kebutuhan dunia kerja yang memerlukan nilai-nilai karakter seperti (1) proaktif, yaitu memiliki inisiatif dalam menghadapi tantangan dan mencapai tujuan-tujuan, (2) membangun konsensus dalam penentuan suatu tujuan, (3) memiliki prioritas yang didasarkan melalui pemikiran-pemikiran mendalam, (4) berpikir dengan kreatif, mencari solusi dan prosedur yang saling menguntungkan, (5) mencari pemahaman terhadap masalahmasalah agar mendapatkan keberhasilan

\footnotetext{
${ }^{7}$ Marsigit, "Implementasi Pendidikan Karakter Pada Bahan Ajar," in Seminar Pendidikan Karakter Pada Bahan Ajar (Seminar Pendidikan, Surakarta: Didikpora Kota Surakarta, 2012).
}

dalam pemecahan masalah, (6) sinergi, yaitu melakukan kerja sama dengan berbagai kelompok, dan (7) ketajaman penglihatan untuk mendorong perbaikan terus menerus ${ }^{8}$.

Nilai budaya dan karakter bangsa di Indonesia bersumber pada agama, Pancasila, budaya, dan tujuan pendidikan nasional. Terdapat 18 nilai budaya dan karakter bangsa yang berasal dari keempat sumber tersebut, yaitu: 1) religius (sikap dan perilaku yang patuh dalam melaksanakan ajaran agama yang dianutnya, toleran terhadap pelaksanaan ibadah agama lain, dan hidup rukun dengan pemeluk agama lain); 2) jujur (perilaku yang didasarkan pada upaya menjadikan dirinya sebagai orang yang selalu dapat dipercaya dalam perkataan, tindakan, dan pekerjaan); 3) toleransi (sikap dan tindakan yang menghargai perbedaan agama, suku, etnis, pendapat, sikap, dan tindakan orang lain yang berbeda dari dirinya); 4) disiplin (tindakan yang menunjukkan perilaku tertib dan patuh pada berbagai ketentuan dan peraturan); 5) kerja keras (perilaku yang menunjukkan upaya sungguh-sungguh dalam mengatasi berbagai hambatan belajar dan tugas, serta menyelesaikan tugas dengan sebaik-baiknya); 6) kreatif (berpikir dan melakukan sesuatu untuk menghasilkan cara atau hasil baru dari sesuatu yang telah dimiliki; 7) mandiri (sikap dan perilaku yang tidak mudah tergantung pada orang lain dalam menyelesaikan tugas-tugas; 8) demokratis (cara berfikir, bersikap, dan bertindak yang menilai sama hak dan kewajiban dirinya

\footnotetext{
${ }^{8}$ Sharron L. McElmeel, Character Education: A Book Guide for Teachers, Librarians, and Parents. (Libraries Unlimited, 2002).
} 
dan orang lain); 9) rasa ingin tahu (sikap dan tindakan yang selalu berupaya untuk mengetahui lebih mendalam dan meluas dari sesuatu yang dipelajarinya, dilihat, dan didengar); 10) semangat kebangsaan (cara berpikir, bertindak, dan berwawasan yang menempatkan kepentingan bangsa dan negara di atas kepentingan diri dan kelompoknya); 11) cinta tanah air (cara berfikir, bersikap, dan berbuat yang menunjukkan kesetiaan, kepedulian, dan penghargaan yang tinggi terhadap bahasa, lingkungan fisik, sosial, budaya, ekonomi, dan politik bangsa); 12) menghargai prestasi (sikap dan tindakan yang mendorong dirinya untuk menghasilkan sesuatu yang berguna bagi masyarakat, dan mengakui, serta menghormati keberhasilan orang lain); 13). bersahabat/komunikatif (tindakan yang memperlihatkan rasa senang berbicara, bergaul, dan bekerja sama dengan orang lain); 14) cinta damai (sikap, perkataan, dan tindakan yang menyebabkan orang lain merasa senang dan aman atas kehadiran dirinya); 15) gemar membaca (kebiasaan menyediakan waktu untuk membaca berbagai bacaan yang memberikan kebajikan bagi dirinya; 16) peduli lingkungan (sikap dan tindakan yang selalu berupaya mencegah kerusakan pada lingkungan alam di sekitarnya, dan mengembangkan upaya-upaya untuk memperbaiki kerusakan alam yang sudah terjadi); 17) peduli sosial (sikap dan tindakan yang selalu ingin memberi bantuan pada orang lain dan masyarakat yang membutuhkan); 18) tanggung-jawab (sikap dan perilaku seseorang untuk melaksanakan tugas dan kewajibannya, yang seharusnya dia lakukan, terhadap diri sendiri, masyarakat, lingkungan, negara dan Tuhan Yang Maha Esa). ${ }^{9}$

Pelaksanaan internalisasi nilai budaya dan karakter bangsa tersebut perlu untuk dievaluasi dan dikembangkan secara berkelanjutan. Terdapat empat tingkatan dalam memberikan penilaian terhadap proses pembangunan karakter yang didasarkan pada hasil pengamatan, catatan anekdotal, tugas, laporan, dan sebagainya. Keempat tingkatan tersebut adalah sebagai berikut. Pertama, Belum Terlihat (BT). Penilaian ini diberikan apabila peserta didik belum memperlihatkan tanda- tanda awal perilaku yang dinyatakan dalam indikator karena belum memahami makna dari nilai itu (Tahap Anomi). Kedua, Mulai Terlihat (MT). Indikatornya adalah peserta didik sudah mulai memperlihatkan adanya tandatanda awal perilaku yang dinyatakan dalam indikator tetapi belum konsisten karena sudah ada pemahaman dan mendapat penguatan lingkungan terdekat (Tahap Heteronomi). Ketiga, Mulai Berkembang (MB). Indikatornya adalah peserta didik sudah memperlihatkan berbagai tanda perilaku yang dinyatakan dalam indikator dan mulai konsisten, karena selain sudah ada pemahaman dan kesadaran juga mendapat penguatan lingkungan terdekat dan lingkungan yang lebih luas (Tahap Sosionomi). Keempat, Membudaya/Menjadi Kebiasaan (MK), apabila peserta didik terus menerus memperlihatkan perilaku yang dinyatakan dalam indikator secara konsisten karena selain sudah ada

\footnotetext{
${ }^{9}$ Tim Penyusun, Pengembangan Pendidikan Budaya Dan Karakter Bangsa.
} 
pemahaman dan kesadaran dan mendapat penguatan lingkungan. ${ }^{10}$

Seiring dengan tuntutan dan perkembangan zaman, pada tahun 2013 terjadi perubahan kurikulum pendidikan dari kurikulum tingkat satuan pendidikan (KTSP) menjadi Kurikulum 2013 (K13). Terdapat tiga alasan utama perlunya pengembangan dan pemberlakuan Kurikulum 2013. Pertama, perubahan proses pembelajaran (dari siswa diberi tahu menjadi siswa mencari tahu) dan proses penilaian (dari berbasis output menjadi berbasis proses dan output) memerlukan penambahan jam pelajaran. Kedua, kecenderungan banyak negara lain yang menambah jam pelajaran. Ketiga, perbandingan dengan negara-negara lain menunjukkan jam pelajaran di Indonesia dengan Negara lain relatif lebih singkat ${ }^{11}$.

Pada tahun 2013, beberapa sekolah-termasuk di Kabupaten Pacitandipilih dan ditetapkan untuk melaksanakan kurikulum 2013, baik pada jenjang sekolah dasar, sekolah menengah pertama, sekolah menengah atas, maupun sekolah menengah kejuruan. Kehadiran kurikulum baru ini tentu menimbulkan pro dan kontra di masyarakat. Banyak masyarakat, orang tua, guru, pakar pendidikan, pengamat dan pakar pendidikan yang memaparkan problematika implementasi K13. Akibatnya pemberlakuan K13 mengalami fluktuasi dan sedang menemukan bentuk ideal.

Penanaman karakter pada K13 tetap menjadi prioritas. Hanya saja, pada kurikulum 2013 tidak secara eksplisit

\footnotetext{
${ }^{10}$ Kementerian Pendidikan Nasional, "Desain Induk Pendidikan Karakter,” 2010.

${ }^{11}$ Kementrian Pendidikan dan Kebudayaan, Modul Pelatihan Implementasi Kurikulum 2013 (Jakarta: Kemendikbud, 2013).
}

menyebutkan secara keseluruhan 18 nilai karakter. Sebagai gantinya, dimunculkan kompetensi inti 1 yang berkenaan dengan sikap keagamaan dan kompetensi inti 2 yang berkenaan dengan sikap sosial. Kompetensi yang berkenaan dengan sikap keagamaan dan sosial dikembangkan secara tidak langsung (indirect teaching).12

Menjadi sangat penting, melakukan penelitian implementasi penanaman nilai karakter dan budaya bangsa melalui kurikulum 2013 di sekolah-sekolah unggulan di Kabupaten Pacitan. Hal ini dimaksudkan agar problematika penanaman nilai karakter dan budaya bangsa segera dapat teratasi. Muaranya adalah terlaksananya kurikulum 2013 dengan baik dan tercapainya tujuan utama pendidikan nasional.

Penelitian ini difokuskan pada implementasi penanaman pendidikan karakter serta pelbagai problematika yang dihadapi oleh sekolah unggulan pada masing-masing jenjang di Kabupaten Pacitan yang telah menerapkan kurikulum 2013, yakni SDN Ploso I, SMPN 1 Pacitan, dan SMAN 1 Pacitan.

\section{B. METODOLOGI PENELITIAN}

Penelitian ini menggunakan pendekatan deskriptif kualitatif dengan metode studi kasus. Pendekatan ini dipilih karena dimaksudkan untuk memahami fenomena tentang apa yang dialami oleh subjek penelitian secara holistik, dan dengan cara deskripsi dalam bentuk katakata dan bahasa, pada suatu konteks khusus yang alamiah dan dengan memanfaatkan

\footnotetext{
${ }^{12}$ Badan Penelitian dan Pengembangan, Kompetensi Dasar Sekolah Menengah Atas (SMA)/Madrasah Aliyah (MA) (Jakarta: Kementerian Pendidikan dan Kebudayaan, 2013).
} 
berbagai metode alamiah ${ }^{13,14}$. Penelitian dilaksanakan mulai bulan Maret hingga bulan Juni 2014. Subjek/responden pada penelitian ini adalah kepala sekolah, guru dan juga siswa dari tiga sekolah yang ditetapkan sebagai lokasi penelitian, yakni SDN Ploso I, SMPN 1 Pacitan, dan SMAN 1 Pacitan. Pengambilan subjek dilakukan secara purposive, dengan menggunakan pertimbangan tertentu, seperti relevansi, pengalaman, dan kemudahan penggalian data $^{15,16}$. Data pada penelitian ini diperoleh dari penelusuran dokumen, observasi, wawancara mendalam, dan focus group discussion (FGD). Sesuai dengan karakteristik penelitian kualitatif, Peneliti sebagai instrumen utama, dibantu dengan instrumen bantu berupa pedoman wawancara, lembar cek lis, dan angket ${ }^{17,18}$.

\section{HASIL DAN PEMBAHASAN}

\section{Muatan Karakter Pada Kurikulum 2013}

Penanaman nilai budaya dan karakter bangsa secara tegas dan eksplisit termuat dalam kurikulum 2013. Standar kompetensi lulusan Sekolah Dasar, Sekolah Menengah Pertama, dan Sekolah Menengah Atas dan atau yang sederajat adalah memuat keharusan untuk memiliki perilaku yang mencerminkan sikap: 1) beriman dan bertakwa kepada Tuhan YME;

\footnotetext{
${ }^{13}$ Lexy J. Moloeng, Metode Penelitian Kualiatif (Bandung: Remaja Rosdakarya, 2007).

${ }^{14}$ Nana Syaodih Sukmadinata, Metode Penelitian Pendidikan (Jakarta: Sinar Harapan, 2008).

${ }^{15}$ Sugiyono, Metode Penelitian Kuantitatif Kualitatif Dan R\&D (Bandung: Alfabeta, 2010).

${ }^{16}$ Sukmadinata, Metode Penelitian Pendidikan.

${ }^{17}$ Louis Cohen, Lawrence Manion, and Keith Morrison, Research Methods in Education (London: Routledge, 2013).

${ }^{18}$ Norman K. Denzin and Yvonna S. Lincoln, The Sage Handbook of Qualitative Research (New York: Sage Publication, 2005).
}

berkarakter, jujur, dan peduli; 3) bertanggung jawab; 4) pembelajar sejati sepanjang hayat; dan 5) sehat jasmani dan rohani sesuai dengan perkembangan anak di lingkungan keluarga, sekolah, masyarakat dan lingkungan alam sekitar, bangsa, dan negara. ${ }^{19}$

Lebih lanjut, standar kompetensi lulusan tersebut diturunkan dalam kompetensi inti dan kompetensi dasar yang juga memuat nilai budaya dan karakter bangsa. Pertama, rumusan kompetensi sikap spiritual pada jenjang sekolah dasar dan atau yang sederajat adalah "Menerima dan menjalankan ajaran agama yang dianutnya". Hal ini mencerminkan adanya target capaian nilai karakter religius. Sementara pada rumusan kompetensi sikap sosialnya adalah "Menunjukkan perilaku jujur, disiplin, tanggung jawab, santun, peduli, dan percaya diri dalam berinteraksi dengan keluarga, teman, dan guru". ${ }^{20}$

Kedua, rumusan kompetensi sikap spiritual pada jenjang sekolah menengah pertama dan atau yang sederajat adalah "Menghargai dan menghayati ajaran agama yang dianutnya". Adapun rumusan kompetensi sikap sosialnya adalah "Menunjukkan perilaku jujur, disiplin, tanggung jawab, peduli (toleran, gotongroyong), santun, dan percaya diri dalam berinteraksi secara efektif dengan

\footnotetext{
19 "Peraturan Menteri Pendidikan Dan Kebudayaan Republik Indonesia Nomor 20 Tahun 2016 Tentang Standar Kompetensi Lulusan Pendidikan Dasar Dan Menengah," 2016.

20 "Peraturan Menteri Pendidikan Dan Kebudayaan Republik Indonesia Nomor 24 Tahun 2016 Tentang Kompetensi Inti Dan Kompetensi Dasar Pelajaran Pada Kurikulum 2013 Pada Pendidikan Dasar Dan Pendidikan Menengah,” 2016.
} 
lingkungan sosial dan alam dalam jangkauan pergaulan dan keberadaannya".21

Ketiga, rumusan kompetensi sikap spiritual pada jenjang sekolah menengah atas dan atau yang sederajat adalah "Menghayati dan mengamalkan ajaran agama yang dianutnya". Adapun rumusan kompetensi sikap sosialnya adalah, "Menunjukkan perilaku jujur, disiplin, tanggung jawab, peduli (gotong-royong, kerja sama, toleran, damai), santun, responsif, dan pro-aktif sebagai bagian dari solusi atas berbagai permasalahan dalam berinteraksi secara efektif dengan lingkungan sosial dan alam serta menempatkan diri sebagai cerminan bangsa dalam pergaulan dunia". ${ }^{22}$

Kompetensi spiritual dan kompetensi sosial pada masing-masing jenjang tersebut dicapai melalui pembelajaran tidak langsung (indirect teaching), yaitu keteladanan, pembiasaan, dan budaya sekolah. dengan memperhatikan karakteristik mata pelajaran, serta kebutuhan dan kondisi peserta didik.

\section{Implementasi penanaman nilai karakter dan budaya bangsa di SDN Ploso I}

Sejak ditetapkan secara resmi pada tahun 2010, SDN Ploso I senantiasa meningkatkan kualitas dan kuantitas pendidikan karakter. Karakter ditanamkan melalui seluruh aktivitas di sekolah. Di antaranya melalui upacara bendera tiap hari Senin, integratif pada setiap pembelajaran, dan melalui kegiatankegiatan ekstrakurikuler. Semuanya telah dilakukan secara berkesinambungan.

\footnotetext{
21 Ibid.

${ }^{22}$ Ibid.
}

Penanaman karakter melalui mata pelajaran matematika juga telah dilakukan oleh para guru SDN Ploso I. Termasuk halnya dengan guru kelas IV SDN Ploso I. Melalui matematika-secara tematikbersama dengan mata pelajaran lain dikolaborasikan untuk menanamkan karakter pada anak. Berdasarkan hasil wawancara dengan responden, yakni guru pengampu kelas IV, diketahui bahwa melalui matematika ditanamkan kedelapan belas karakter utama. Kedelapan belas karakter tersebut adalah religius; jujur; toleransi; disiplin; kerja keras; kreatif; mandiri; demokratis; rasa ingin tahu; semangat kebangsaan; cinta tanah air; menghargai prestasi; bersahabat/ komunikatif; cinta damai; gemar membaca; peduli lingkungan; peduli sosial, dan tanggung jawab. Informasi ini dipertegas oleh data hasil dokumentasi terhadap perangkat pembelajaran dan juga observasi yang dilakukan oleh peneliti.

Informasi lebih lanjut, berdasarkan hasil evaluasi responden, diketahui bahwa dari kedelapan belas karakter tersebut, sebagian besar telah membudaya, dan hanya beberapa yang masih dalam tahap mulai berkembang. Berikut adalah data hasil evaluasi penanaman karakter melalui mata pelajaran matematika di SDN Ploso I.

Hasil tersebut mengindikasikan bahwa mata pelajaran matematika - secara bersama-sama dengan mata pelajaran lain- memberikan dampak yang cukup baik dalam penanaman nilai budaya dan karakter bangsa. Karena mata pelajaran di sekolah dasar bersifat tematik, maka implementasinya pun tidak bisa berdiri sendiri. 
Implementasi penanaman nilai karakter dan budaya bangsa di SMPN 1 Pacitan

Sebagai SMP terbaik di Kabupaten Pacitan, tentu SMP N 1 Pacitan menjadi sekolah yang senantiasa menerapkan setiap kebijakan terbaru pemerintah. Termasuk halnya dengan implementasi pendidikan karakter. Baik melalui mata pelajaran, pembiasaan, maupun kegiatan ekstrakurikuler. Penanaman karakter yang terintegrasi pada mata pelajaran menjadi salah satu upaya dalam menanamkan dan menumbuhkan nilai budaya dan karakter bangsa.

Mata pelajaran matematika tidak terkecuali menjadi mata pelajaran yang digunakan untuk menanamkan dan menumbuhkan nilai budaya dan karakter bangsa. Penanaman karakter melalui mata pelajaran matematika telah dilakukan sejak tahun 2010. Seiring dengan perubahan kurikulum, dari semula KTSP menjadi kurikulum 2013, proses dalam mengimplementasikan nilai budaya dan karakter mengalami penyesuaian. Berdasarkan hasil wawancara dengan responden, yakni guru pengampu mata pelajaran matematika kelas VII, diketahui bahwa seluruh nilai budaya dan karakter bangsa yang tercantum pada buku panduan, telah dilaksanakan. Hal ini diperkuat dengan data hasil dokumentasi terhadap perangkat pembelajaran mata pelajaran matematika dan juga observasi yang dilakukan oleh peneliti terhadap guru mata pelajaran matematika. Penanaman nilai budaya dan karakter bangsa dilakukan secara eksplisit dengan mengintegrasikan pada setiap kegiatan belajar mengajar.

Berdasarkan hasil evaluasi responden, diketahui bahwa dari kedelapan belas nilai budaya dan karakter bangsa tersebut,

Tabel 1. Hasil Evaluasi Implementasi Pendidikan Karakter melalui Mata Pelajaran Matematika

\begin{tabular}{llll}
\hline \multicolumn{1}{c}{ Nilai karakter } & \multicolumn{1}{c}{ SDN Ploso I } & \multicolumn{1}{c}{ SMPN 1 Pacitan } & SMAN 1 Pacitan \\
\hline \hline Religius & Mulai berkembang & Mulai berkembang & Telah membudaya \\
Jujur & Telah membudaya & Mulai berkembang & Mulai berkembang \\
Toleransi & Telah membudaya & Mulai berkembang & Telah membudaya \\
Disiplin & Mulai berkembang & Mulai berkembang & Telah membudaya \\
Kerja keras & Mulai berkembang & Mulai terlihat & Mulai berkembang \\
Kreatif & Mulai terlihat & Mulai terlihat & Mulai berkembang \\
Mandiri & Mulai berkembang & Mulai terlihat & Mulai berkembang \\
Demokratis & Telah membudaya & Mulai berkembang & Mulai berkembang \\
Rasa ingin tahu & Mulai terlihat & Mulai berkembang & Mulai berkembang \\
Semangat kebangsaan & Telah membudaya & Mulai terlihat & Telah membudaya \\
Cinta tanah air & Telah membudaya & Mulai terlihat & Telah membudaya \\
Menghargai prestasi & Mulai terlihat & Mulai terlihat & Telah membudaya \\
Bersahabat/ komunikatif & Mulai berkembang & Mulai berkembang & Telah membudaya \\
Cinta damai & Mulai berkembang & Mulai berkembang & Telah membudaya \\
Gemar membaca & Belum terlihat & Mulai terlihat & Mulai berkembang \\
Peduli lingkungan & Mulai berkembang & Mulai terlihat & Mulai berkembang \\
Peduli sosial & Mulai berkembang & Mulai berkembang & Mulai berkembang \\
Tanggung jawab & Belum terlihat & Mulai terlihat & Telah membudaya \\
\hline
\end{tabular}


sebagian besar telah mulai berkembang. Artinya, peserta didik telah mampu memperlihatkan prilaku karakter sesuai indikator yang telah ditetapkan dan mulai konsisten. Beberapa nilai budaya dan karakter bangsa lainnya masih dalam tahap mulai terlihat.

Data implementasi dari guru ini dikuatkan dengan data dari siswa. Berdasarkan angket yang disebarkan pada siswa SMPN 1 Pacitan, diketahui bahwa sebagian besar siswa merasa mengalami perubahan karakter antara sebelum dan sesudah belajar matematika.

\section{Implementasi penanaman nilai karakter dan budaya bangsa di SMAN 1 Pacitan}

Sebagaimana dua sekolah yang telah dipaparkan sebelumnya, SMAN 1 Pacitan tidak ketinggalan dalam menanamkan nilai budaya dan karakter bangsa. Sekolah tidak hanya menuntut siswa-siswinya untuk berprestasi secara akademik saja, namun juga mengarahkan pada penanaman nilai budaya dan karakter bangsa. Penanamannya pun dilakukan dari berbagai penjuru. Baik melalui kegiatan pembelajaran, pembiasaan, kegiatan ekstrakurikuler dan lain sebagainya.

Matematika sebagai salah satu mata pelajaran wajib, memegang peranan yang cukup penting dalam menanamkan dan menumbuhkan nilai budaya dan karakter bangsa. Berdasarkan hasil wawancara dengan responden, yakni guru pengampu mata pelajaran kelas $\mathrm{X}$, diketahui guru matematika telah berupaya untuk menanamkan delapan belas nilai budaya dan karakter bangsa.

Informasi ini dipertegas oleh data hasil dokumentasi terhadap perangkat pembelajaran mata pelajaran matematika dan juga observasi yang dilakukan oleh peneliti. Upaya penanaman karakter ini terlihat dari perangkat pembelajaran yang disusun oleh guru. Penanaman nilai budaya dan karakter bangsa dilakukan secara

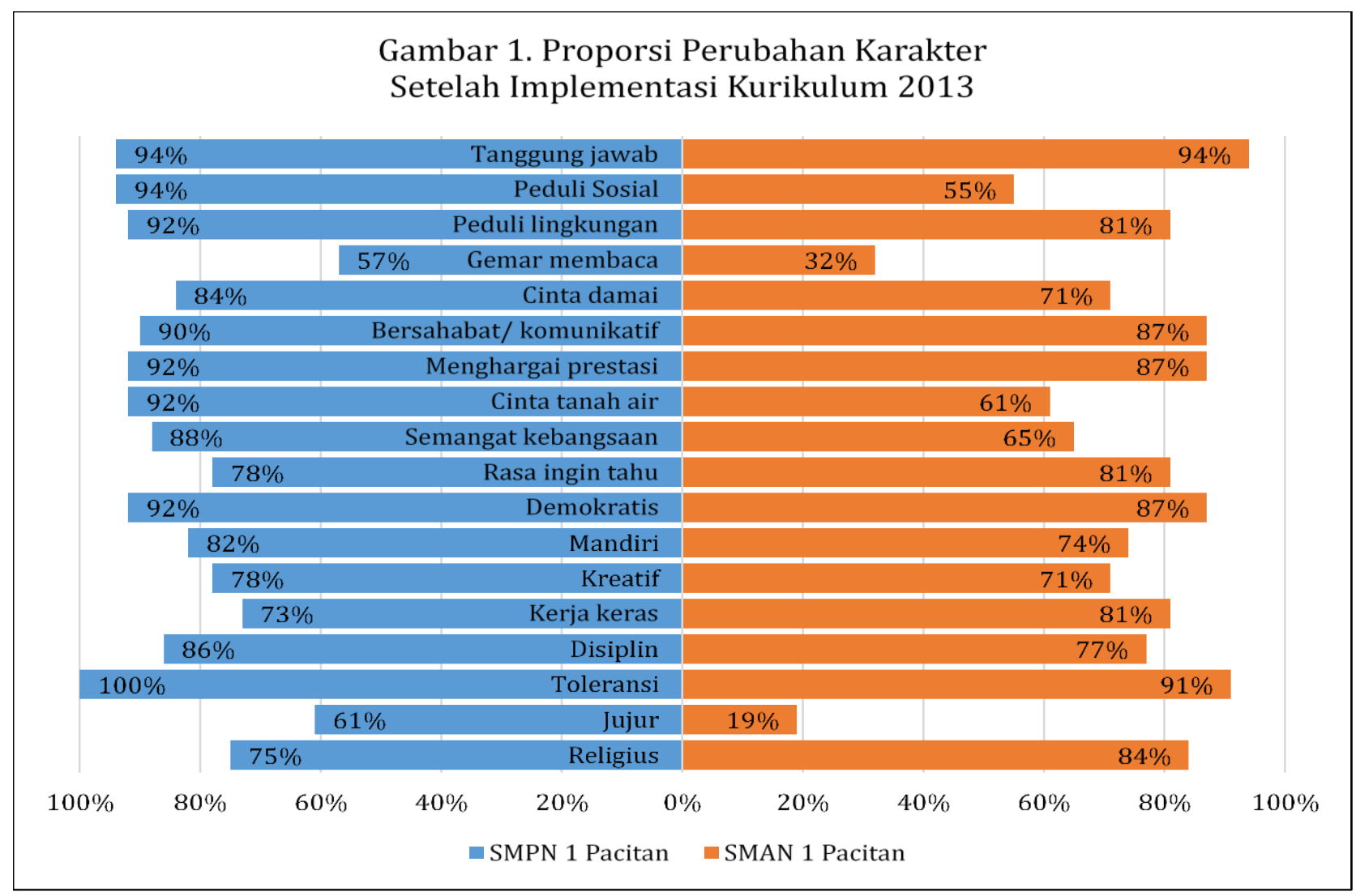


terintegrasi pada proses pembelajaran, sesuai dengan materi yang menjadi pokok kajian. Artinya, pada proses pembelajaran tertentu, hanya nilai budaya dan karakter bangsa tertentu pula lah yang ditanamkan.

Lebih lanjut, berdasarkan angket dan wawancara mendalam dengan responden, diketahui gambaran hasil evaluasi terhadap penanaman nilai budaya dan karakter bangsa pada kurikulum 2013, khususnya melalui mata pelajaran matematika. Penilaian tersebut didasarkan pada anecdotal record, catatan yang dibuat guru berdasarkan observasi.

Data implementasi dari guru ini dikuatkan dengan data dari siswa. Berdasarkan angket yang disebarkan pada siswa kelas X SMAN 1 Pacitan, diketahui bahwa sebagian besar siswa merasa mengalami perubahan karakter antara sebelum mengikuti mata pelajaran matematika dan sesudahnya.

\section{Problematika penanaman nilai karakter dan budaya bangsa di SDN Ploso I}

Hasil angket yang diperkuat wawancara mendalam dengan Guru Kelas IV, diketahui bahwa secara umum, dalam hal menanamkan nilai budaya dan karakter bangsa secara terintegrasi pada mata pelajaran, tidak menjadi masalah. Karena kurikulum 2013 telah disusun sejalan dengan penanaman nilai-nilai budaya dan karakter bangsa. Sehingga Guru dapat mengantarkan siswa untuk memahami dan menguasai materi yang dipelajari, sekaligus memperoleh pemaknaan nilai budaya dan karakter bangsa.

Keseimbangan antara ranah kognitif, afektif, dan psikomotor menjadi suatu hal yang penting untuk dilaksanakan. Guru harus mampu menjadi 'sutradara' yang baik di kelas. Guru memiliki begitu banyak peran. Mulai dari menyusun skenario dan setting pembelajaran, menjadi 'pemain' di dalamnya, sekaligus menjadi 'manager' bagi seluruh siswa yang menjadi pemain di dalamnya. Guru dituntut harus mampu menyusun skenario dan setting pembelajaran yang mampu membuat siswa bisa belajar secara aktif, sekaligus mendapatkan berbagai nilai budaya karakter bangsa yang ditetapkannya.

Problematika utama dalam penanaman nilai budaya dan karakter adalah dalam hal penilaian. Penilaian nilai budaya dan karakter terlalu rumit dan menyita waktu banyak, karena dilakukan setiap hari. Selain itu, pengamatan guru terhadap siswa juga terbatas. Terbatas oleh ruang dan waktu. Pengamatan sebagai dasar penilaian hanya sebatas pada sikap dan perilaku siswa di sekolah. Sementara waktu terpanjang siswa adalah di rumah atau keluarga masingmasing. Sehingga tidak menutup kemungkinan terdapat beberapa siswa yang bersifat kamuflase. Di depan Bapak/Ibu Guru tampil baik, namun apabila di luar sekolah, atau di luar jangkauan Bapak/Ibu guru tidak demikian.

Problematika lainnya adalah ketika Guru harus mengamati aktivitas seluruh siswa selama proses belajar mengajar. Tentu pengamatan tersebut harus secara proporsional dan lebih intens. Karena kesalahan dalam pengamatan, akan berakibat pada kesalahan dalam pemberian penilaian. Banyaknya anecdotal record akan membuat Guru semakin lebih sulit lagi dalam memaknainya. Di samping itu, penilaian terhadap karakter seorang peserta didik tidak bersifat mutlak. Besar 
peluang terjadi, setelah diberi nilai karakter yang baik, seorang siswa tiba-tiba berubah menjadi berkarakter yang tidak baik.

Terlebih lagi, banyaknya nilai karakter yang harus diamati sekaligus diberikan penilaian, juga menjadi kendala tersendiri. Guru membutuhkan waktu untuk dapat mengamati sekaligus memberikan penilaian. Akan lebih rumit lagi apabila seorang guru mengampu lebih dari satu kelas. Dengan siswa yang lebih banyak, tentu Guru akan bekerja lebih rumit. Karena untuk bisa memberikan penilaian, prasyarat utamanya adalah Guru harus mampu mengenal nama seluruh siswa yang berada di kelasnya. Sehingga, semakin banyak kelas, semakin banyak nama siswa yang harus diketahuinya. Hal ini membuat beban guru sebagai fasilitator, motivator, dan salah satu sumber belajar di kelas semakin tinggi.

Selain tersebut di atas, problematika lainnya adalah padatnya materi yang harus dipelajari pada kurikulum 2013. Hasil wawancara dengan Guru kelas IV, diketahui bahwa materi pada kurikulum 2013 cukup banyak. Terkadang terdapat beberapa materi yang mestinya tidak diberikan pada siswa kelas IV SD. Pada dasarnya Guru diberikan keleluasaan untuk membuat skenario pembelajaran tersendiri, agar semua dapat tercapai. Namun, tugas Guru dalam manajemen waktu dirasa berat. Misalnya, tuntutan pembelajaran pada suatu tema adalah dua hingga tiga jam pertemuan. Padahal, jikalau dilaksanakan dengan mengutamakan proses, diperkirakan empat hingga lima jam pertemuan baru selesai. Hal ini yang membutuhkan waktu untuk Guru belajar dan beradaptasi dengan kurikulum 2013.

\section{Problematika penanaman nilai karakter dan budaya bangsa di SMPN 1 Pacitan}

Hasil angket yang diperkuat wawancara mendalam dengan Guru Kelas VII SMPN 1 Pacitan, dapat dikatakan bahwa secara umum, dalam hal menanamkan nilai budaya dan karakter bangsa secara terintegrasi pada mata pelajaran matematika tidak terdapat permasalahan yang berarti. Karena kurikulum 2013 telah disusun sejalan dengan penanaman nilai-nilai budaya dan karakter bangsa. Sehingga Guru dapat membawa siswa untuk memahami dan menguasai materi yang dipelajari, sekaligus memperoleh pemaknaan di dalamnya. Pemaknaan akan nilai-nilai budaya dan karakter bangsa.

Problematika yang terjadi dalam penanaman nilai budaya dan karakter bangsa tidak terlepas dari problematika implementasi kurikulum 2013. Problematika dalam mengimplementasikan kurikulum 2013 yang dirasakan Guru adalah padatnya materi yang harus dipelajari siswa. Hasil wawancara dengan Guru kelas VII SMPN 1 Pacitan, diketahui bahwa materi matematika pada kurikulum 2013 cukup banyak dan pada beberapa materi dirasakan terlalu tinggi untuk ukuran siswa SMP. Pada dasarnya Guru diberikan keleluasaan untuk membuat skenario pembelajaran tersendiri, agar semua dapat tercapai. Namun, tugas Guru dalam manajemen waktu dirasa berat. Misalnya, tuntutan pembelajaran pada suatu tema adalah dua hingga tiga jam pertemuan. Padahal, jikalau dilaksanakan dengan mengutamakan proses, diperkirakan empat hingga lima jam pertemuan baru selesai. Hal ini yang 
membutuhkan waktu untuk Guru belajar dan beradaptasi dengan kurikulum 2013.

Tingginya materi yang dipelajari, membuat disparitas antara siswa yang pandai dan kurang pandai. Siswa pandai cenderung lebih cepat untuk bisa memahami, namun sebagian siswa lain yang kurang pandai lebih lama memahaminya. Pembelajaran yang dibuat pendekatan ilmiah (Scientific methode) belum mampu menyelesaikan permasalahan ini. Belum mampu menjadi katalisator disparitas pemahaman matematika siswa.

Tuntutan penilaian pada ketiga ranah, yakni kognitif, afektif, dan psikomotor dirasakan memberatkan Guru. Di satu sisi Guru masih harus beradaptasi dalam membuat 'scenario' pembelajaran yang sesuai dengan kurikulum 2013, di sisi lain Guru juga harus mampu memberikan penilaian yang autentik. Sehingga hal ini akan menjadi problematika juga dalam mengintegrasikan karakter pada mata pelajaran matematika.

Penilaian nilai budaya dan karakter terlalu rumit dan menyita waktu banyak, karena dilakukan setiap hari. Mengingat penilaian karakter, merupakan penilaian sikap dan perilaku. Keduanya bersifat nisbi, yang dapat berubah sewaktu-waktu dan dapat berubah menurut pengamatan oleh orang yang berbeda. Selain itu, pengamatan guru terhadap siswa juga terbatas. Terbatas oleh ruang dan waktu. Pengamatan sebagai dasar penilaian hanya sebatas pada sikap dan perilaku siswa di sekolah. Sementara waktu terpanjang siswa adalah di rumah atau keluarga masing-masing. Sehingga tidak menutup kemungkinan terdapat beberapa siswa yang bersifat kamuflase. Di depan Bapak/Ibu Guru tampil baik, namun apabila di luar sekolah, atau di luar jangkauan Bapak/Ibu guru tidak demikian.

Problematika lainnya adalah ketika Guru harus mengamati aktivitas seluruh siswa selama proses belajar mengajar. Tentu pengamatan tersebut harus secara proporsional dan lebih intens. Karena kesalahan dalam pengamatan, akan berakibat pada kesalahan dalam pemberian penilaian. Banyaknya anecdotal record akan membuat Guru semakin lebih sulit lagi dalam memaknainya. Di samping itu, penilaian terhadap karakter seorang peserta didik tidak bersifat mutlak. Bisa jadi, sebelum diberikan penilaian, seorang siswa itu memiliki karakter yang baik, namun setelah diberi penilaian tiba-tiba berubah karakternya menjadi tidak baik.

Terlebih lagi, banyaknya nilai karakter yang harus diamati sekaligus diberikan penilaian, juga menjadi kendala tersendiri. Guru membutuhkan waktu untuk dapat mengamati sekaligus memberikan penilaian. Akan lebih rumit lagi apabila seorang guru mengampu lebih dari satu kelas. Dengan siswa yang lebih banyak, tentu Guru akan bekerja lebih rumit. Karena untuk bisa memberikan penilaian, prasyarat utamanya adalah Guru harus mampu mengenal nama seluruh siswa. Akibatnya, semakin banyak kelas, semakin banyak nama siswa yang harus diketahuinya. Hal ini membuat beban guru sebagai fasilitator, motivator, dan salah satu sumber belajar di kelas semakin tinggi.

\section{Problematika penanaman nilai karakter dan budaya bangsa di SMAN 1 Pacitan}

Hasil angket yang diperkuat wawancara mendalam dengan Guru Kelas VII SMAN 1 Pacitan, dapat dikatakan bahwa secara 
umum, dalam hal menanamkan nilai budaya dan karakter bangsa secara terintegrasi pada mata pelajaran matematika tidak terdapat permasalahan yang berarti. Karena kurikulum 2013 telah disusun sejalan dengan penanaman nilai-nilai budaya dan karakter bangsa. Sehingga Guru dapat membawa siswa untuk memahami dan menguasai materi yang dipelajari, sekaligus memperoleh pemaknaan di dalamnya.

Problematika yang terjadi dalam penanaman nilai budaya dan karakter bangsa tidak terlepas dari problematika implementasi kurikulum 2013. Problematika dalam mengimplementasikan kurikulum 2013 yang dirasakan Guru adalah padatnya materi matematika yang harus dipelajari siswa. Hasil wawancara dengan Guru kelas X SMAN 1 Pacitan, diketahui bahwa materi matematika pada kurikulum 2013 cukup banyak. Hal ini disiasati dengan melakukan distribusi materi secara proporsional pada kelas XI dan XII. Dengan sistematika materi yang baik, akan memperlancar proses belajar mengajar mata pelajaran matematika.

Tuntutan penilaian pada ketiga ranah, yakni kognitif, afektif, dan psikomotor tidak dirasakan berat oleh Guru mata pelajaran matematika. Pasalnya, hasil pengamatan selama ini, terdapat kecenderungan bahwa siswa yang aktif dan memiliki karakter yang baik cenderung memiliki prestasi akademik (kognitif) yang baik pula. Demikian juga sebaliknya, siswa yang memiliki prestasi akademik (kognitif) yang baik, cenderung memiliki karakter yang baik.

Problematika lainnya adalah ketika Guru harus mengamati aktivitas seluruh siswa selama proses belajar mengajar. Tentu pengamatan tersebut harus secara proporsional dan lebih intens. Karena kesalahan dalam pengamatan, akan berakibat pada kesalahan dalam pemberian penilaian. Banyaknya anecdotal record akan membuat Guru semakin lebih sulit lagi dalam memaknainya. Di samping itu, penilaian terhadap karakter seorang peserta didik tidak bersifat mutlak. Bisa jadi, sebelum diberikan penilaian, seorang siswa itu memiliki karakter yang baik, namun setelah diberi penilaian tiba-tiba berubah karakternya menjadi tidak baik.

Terlebih lagi, banyaknya nilai karakter yang harus diamati sekaligus diberikan penilaian, juga menjadi kendala tersendiri. Guru membutuhkan waktu untuk dapat mengamati sekaligus memberikan penilaian. Akan lebih rumit lagi apabila seorang guru mengampu lebih dari satu kelas. Dengan siswa yang lebih banyak, tentu Guru akan bekerja lebih rumit. Karena untuk bisa memberikan penilaian, prasyarat utamanya adalah Guru harus mampu mengenal nama seluruh siswa yang berada di kelasnya. Sehingga, semakin banyak kelas, semakin banyak nama siswa yang harus diketahuinya. Hal ini membuat beban guru sebagai fasilitator, motivator, dan salah satu sumber belajar di kelas semakin tinggi.

Hasil di atas menunjukkan bahwa problematika utama dalam penanaman karakter pada kurikulum 2013 terletak pada guru. kesulitan dalam mengintegrasikan pendidikan karakter dalam pembelajaran, kesulitan dalam mengembangkan kompetensi sikap, pengetahuan dan keterampilan secara terpadu. Hal ini diakibatkan oleh beberapa faktor seperti ketidakcukupan waktu karena muatan isi terlalu luas; perlunya 
adaptasi dalam penerapan pembelajaran saintifik, tematik terpadu, dan konstruktivistik dalam pembelajaran; dan kesulitan kesulitan dalam membuat penilaian. Hasil ini sejalan dengan penelitian lain yang dilakukan oleh Syarwan Ahmad $^{23}$ dan Maisyaroh dkk ${ }^{24}$.

Matematika tidak hanya dapat digunakan untuk mengembangkan ranah kognitif, tetapi juga untuk mengeksplorasi ranah-ranah yang lainnya. Salah satunya, proses pembelajaran matematika dapat digunakan untuk menanamkan dan menguatkan motivasi, apresiasi atau penghargaan siswa terhadap matematika, kontribusi siswa dalam pembelajaran, interest (minat kuat), beliefs (sikap mental yakin), confidence (sikap mental percaya) dan perseverance (ketekunan, kekuatan hati, kegigihan). ${ }^{25}$ Nilai utama budaya dan karakter bangsa yang dapat ditanamkan dalam proses pembelajaran matematika adalah berpikir logis, kritis, kerja keras, keingintahuan, kemandirian, percaya diri. Selain itu, matematika juga dapat digunakan untuk menanamkan kereligiusan, kejujuran, cerdas, tangguh, peduli dan demokratis. ${ }^{26}$ Pembelajaran matematika cukup efektif

\footnotetext{
${ }^{23}$ Syarwan Ahmad, "Problematika Kurikulum 2013 Dan Kepemimpinan Instruksional Kepala Sekolah," Jurnal Pencerahan 8, no. 2 (2014).

${ }^{24}$ Wildan Zulkarnain, Arbin Janu Setyowati, and Susriyati Mahanal, "Masalah Guru Dalam Implementasi Kurikulum 2013 Dan Kerangka Model Supervisi Pengajaran," trans. Maisyaroh, Manajemen Pendidikan 24, no. 3 (2014): 213.

${ }^{25}$ Agung Prabowo and Pramono Sidi, "Memahat Karakter Melalui Pembelajaran Matematika" (The 4 th International Conference on Teacher Education; Join Conference UPI \& UPSI, Bandung, 2010).

${ }^{26}$ Edi Prayitno and Widyantini, Pendidikan Nilai-Nilai Budaya Dan Karakter Bangsa Dalam Pembelajaran Matematika Di SMP (Yogyakarta: PPPPTK Matematika, 2011).
}

dalam meningkatkan prestasi dan sekaligus nilai-nilai karakter dan budaya bangsa. ${ }^{27}$

\section{PENUTUP}

Berdasarkan hasil penelitian dan pembahasan di atas, dapat disusun beberapa simpulan sebagai berikut. Pertama, penanaman nilai budaya dan karakter bangsa terkandung dalam kurikulum 2013. Secara eksplisit, berbagai muatan nilai budaya dan karakter bangsa tersebut tercantum pada standar kompetensi lulusan dan rumusan kompetensi aspek sikap spiritual serta rumusan kompetensi aspek sikap sosial. Kedua, implementasi penanaman karakter dan budaya bangsa melalui pembelajaran matematika di jenjang sekolah dasar dan sekolah menengah telah terlaksana. Pembelajaran matematika juga relevan untuk menanamkan nilai budaya dan karakter bangsa, melalui pembelajaran tidak langsung (indirect teaching). Matematika lebih relevan untuk menanamkan nilai kejujuran, kerja keras, tanggung jawab, berpikir logis, kritis, kreatif, dan inovatif. Ketiga, problematika implementasi penanaman nilai budaya dan karakter bangsa bertalian erat dengan problematika kurikulum 2013, yakni keluasan materi, sistematika materi, penilaian, dan proses adaptasi guru.

\section{E. DAFTAR PUSTAKA}

Ahmad, Syarwan. "Problematika Kurikulum 2013 Dan Kepemimpinan Instruksional Kepala Sekolah." Jurnal Pencerahan 8, no. 2 (2014).

Badan Penelitian dan Pengembangan. Kompetensi Dasar Sekolah Menengah

\footnotetext{
${ }^{27}$ Salafudin, "Pendidikan Karakter Melalui Pembelajaran Matematika” 10, no. 1 (2013).
} 
Atas (SMA)/Madrasah Aliyah (MA). Jakarta: Kementerian Pendidikan dan Kebudayaan, 2013.

Cohen, Louis, Lawrence Manion, and Keith Morrison. Research Methods in Education. London: Routledge, 2013.

Denzin, Norman K., and Yvonna S. Lincoln. The Sage Handbook of Qualitative Research. New York: Sage Publication, 2005.

Kementrian Pendidikan dan Kebudayaan. Modul Pelatihan Implementasi Kurikulum 2013. Jakarta: Kemendikbud, 2013.

Marsigit. "Implementasi Pendidikan Karakter Pada Bahan Ajar." In Seminar Pendidikan Karakter Pada Bahan Ajar. Surakarta: Didikpora Kota Surakarta, 2012.

- - - "Pengembangan Nilai-Nilai Matematika Dan Pendidikan Matematika Sebagai Pilar Pembangunan Karakter Bangsa." In Seminar Nasional Pengembangan Nilai-Nilai Dan Aplikasi Dalam Dunia Matematika Sebagai Pilar Pembangunan Karakter Bangsa. Semarang: Universitas Negeri Semarang, 2011.

McElmeel, Sharron L. Character Education: A Book Guide for Teachers, Librarians, and Parents. Libraries Unlimited, 2002.

Moloeng, Lexy J. Metode Penelitian Kualiatif. Bandung: Remaja Rosdakarya, 2007.

Nasional, Kementerian Pendidikan. "Desain Induk Pendidikan Karakter," 2010.

Pemerintah Republik Indonesia. Kebijakan Nasional Pembangunan Karakter Bangsa Tahun 2010-2025. Jakarta: Pemerintah Republik Indonesia, 2010.

"Peraturan Menteri Pendidikan Dan Kebudayaan Republik Indonesia Nomor 20 Tahun 2016 Tentang Standar Kompetensi Lulusan
Pendidikan Dasar Dan Menengah," 2016.

"Peraturan Menteri Pendidikan Dan Kebudayaan Republik Indonesia Nomor 24 Tahun 2016 Tentang Kompetensi Inti Dan Kompetensi Dasar Pelajaran Pada Kurikulum 2013 Pada Pendidikan Dasar Dan Pendidikan Menengah," 2016.

Prabowo, Agung, and Pramono Sidi. "Memahat Karakter Melalui Pembelajaran Matematika." Bandung, 2010.

Prayitno, Edi, and Widyantini. Pendidikan Nilai-Nilai Budaya Dan Karakter Bangsa Dalam Pembelajaran Matematika Di SMP. Yogyakarta: PPPPTK Matematika, 2011.

Salafudin. "Pendidikan Karakter Melalui Pembelajaran Matematika" 10, no. 1 (2013).

Sugiyono. Metode Penelitian Kuantitatif Kualitatif Dan R\&D. Bandung: Alfabeta, 2010.

Sukmadinata, Nana Syaodih. Metode Penelitian Pendidikan. Jakarta: Sinar Harapan, 2008.

Tim Penyusun. Pengembangan Pendidikan Budaya Dan Karakter Bangsa. Jakarta: Pusat Kurikulum Badan Pusat Penelitian dan Pengembangan Kemendiknas, 2010.

"Undang-Undang Republik Indonesia Nomor 20 Tahun 2003 Tentang Sistem Pendidikan Nasional," 2003.

"Undang-Undang RI Nomor 17 Tahun 2007 Tentang Rencana Pembangunan Jangka Panjang Nasional Tahun 2005-2025," 2007.

Zulkarnain, Wildan, Arbin Janu Setyowati, and Susriyati Mahanal. "Masalah Guru Dalam Implementasi Kurikulum 2013 Dan Kerangka Model Supervisi Pengajaran." Translated by Maisyaroh. Manajemen Pendidikan 24, no. 3 (2014):

213. 